\section{Research Article}

(C) 2021 Hussein et al. This is an open access article licensed under the Creative Commons Attribution-NonCommercial 4.o International License (https://creativecommons.org/licenses/by-nc/4.o/)

\title{
The Impact of Strategic Planning in the University's Competitiveness According to NIAS
}

\author{
Dr. Abbas Mohammed Hussein \\ Mohammed Mustafa Ahmed ${ }^{2}$ \\ Dr. Mohamed Yahya Mahmoud Khu \\ ${ }^{1}$ The University of Mashreq, Baghdad, Iraq \\ ${ }^{2}$ College of Graduate Studies, Universiti Tenaga Nasional, Kajang, Malaysia
}

DOI: https://doi.org/10.36941/ajis-2021-0125

\section{Abstract}

Competition is one of the realities of the business environment, and despite this, the awareness of organizations (especially in developing countries) of the importance of dealing with it has not yet developed until in recent years. Developing countries are unable to follow these methods so that these competitive situations will be deeper and more powerful due to the clear interaction between not following the scientific method and adhering to random and improvisational methods, which is reflected in the capabilities of these organizations. The research deals with the impact of strategic planning (external orientation, internal orientation, functional coverage, and resources provided for strategic planning) in the university's competitiveness (the strategy of the educational institution, Governance and management, Financial and material resources, Faculty members, Students, Scientific research, Community service, Curricula), as an expression of a vision of the role of strategic planning in achieving effective adaptation to competitive situations and improving the university's competitiveness, to establish a reality in the minds of the leaders responsible for the planning process that working in traditional contexts in light of the changes and accumulating problems of the Iraqi environment leads to results that are not effective concerning the size of the problems. Hence, the research problem arises by raising a major question which is: What is the impact of strategic planning on the competitiveness of Iraqi universities according to the national institutional accreditation standards of the Iraqi Ministry of Higher Education and Scientific Research? To achieve the goal of the research and answer its questions, the research applied to a sample of (158) individuals at the University of Technology and the research adopted the questionnaire to collect the data that were processed and analyzed using several statistical methods. The research reached several results, including the researched university has employed strategic planning with all its indicators to improve its competitiveness. the most important recommendations were the necessity for the university to employ more strategic planning to improve the university's competitiveness.

Keywords: Strategic Planning, Competitiveness, University, NIAS, Malaysia

\section{Introduction}

It has become clear that the goal that any organization aspires to reach is to achieve competitiveness, in light of globalization punctuated by a revolution in the field of communications and informatics, 
and in light of the spread of the internet that has broken barriers and made the world open for everyone to promote their services.

The above justifications have pushed organizations to search and investigate more modern methods of management that can face contemporary challenges, leading to inject life into the organizations, and attention has been directed to strategic planning, which organizations considered an effective means to bring about radical changes in the philosophy and method of work in them and use it as a bridge to reach to the satisfaction of the beneficiaries, who became the goal of gaining their loyalty and retaining them a strategic gain for the organization. Although strategic planning is a concept and components that have saturated research by theorists, its decision on the practical level is still a stand-alone problem, especially in Iraq.

Strategic planning represents administrative mean necessary to accomplish the strategic goals of organizations, as it enables correct decisions to be made, helps in obtaining information, clarifies strategic direction, and enhances coordination and control through performance review, to achieve competitiveness. However, despite the above facts, it can be said that Iraqi universities do not rely on a scientific approach to planning, which is reflected in their low competitiveness among their international counterparts. Moreover, searching in particular Arab databases reveals that the number of studies that dealt with strategic planning issues, and competitiveness, in particular, is relatively few. For example, when searching the database of Iraqi academic journals, we can find (151) studies dealing with strategic planning, and (15) related to competitiveness, and this is a relatively small number as we take into account the theoretical importance that the specialized literature gives to these topics, and compared to the number of researches that we can find in foreign databases. To bridge this gap, this research aims to conduct a comprehensive study linking strategic planning with competitiveness in one of the important sectors, which is the education sector. Consequently, the second part of the research delves into the philosophical underpinnings of strategic planning and competitiveness, the third part is devoted to clarifying the problem by tracing the research approach and its introductory framework, the results are presented and analyzed and hypotheses tested in Section Four, arriving at the conclusions and recommendations in section five.

\section{Literature Review}

\subsection{Strategic Planning}

In recent years, there has been an increase in the use of the concept of planning in general and strategic planning in particular, within the managerial concepts that the organization must adopt if it wants to achieve the goals for which it was established and ensure its continuation and survival. There are multiple concepts that researchers have put forward about it that are consistent in their content in several aspects, and the researcher can limit them according to two directions. The first trend sees strategic planning as a set of formal and informal human interactions that occur during the process of generating strategic plans (Dutton \& Duncan, 1987), (Raman, 2009). It is a long-term planning process that focuses on the organization as a whole (Derto, 1997). The outcome of this process is embodied in the comprehensive plans of the organization, including a set of decisions dealing with strategic issues (Gerard \& St-Hillier, 2011). It defines broad and flexible goals, realization policies, and leads the organization towards its future vision (Ghezzi et al, 2010). By prioritizing the use of resources, and according to specific goals, in an attempt to direct their direction and development over a period of time (Kriemadis \& Theakou, 2007).

While the advocate of the second trend see strategic planning as a commitment to thinking about the future and how to achieve it strategically, which constitutes a procedure much more than just preparing a strategic plan. In this vein, Nayga \& Bagal (1995) describes it as a set of specific organizational tasks and procedures to ensure appropriate information is obtained, environmental forecasting is undertaken, and strategic options are dealt with and evaluated in a consistent and timely manner. According to (Berry \& Wechsler, 1995) the strategic planning is a systematic process 
for managing the organization and its future directions in relation to the environment and stakeholder requirements. Williams (2002) agrees with the above definition and define strategic planning as a process of insight into the future of the organization, through which the organization looks towards the future to define a vision, create a message, and develop values and guiding principles. And work on exploring the competitive environment, analyzing strategic alternatives, and then coordinating implementation moves throughout the organization (Andersen, 2004). while Korosec (2006) described it as a review of the strategic factors that the organization face, in an attempt to achieve a better understanding of the stakeholders, the organization's mission, and goals, and to find more creative strategies to allow the organization to work more successfully. Speaking about strategic planning, (Armstrong et al, 2014) affirms that strategic planning means the process of finding a strategic fit between the goals and capabilities of the organization and its changing market opportunities. As well as being a tool for organizing the current situation on the basis of assumptions of the desired future (Bdair, 2011).

Strategic planning represents a process and a philosophy, it determines the purpose of the organization and its desired location in the future and then develops the best path to reach that site, a process used to develop, evaluate and amend the strategies of the organization (Notarantonio \& Quigley, 2001). It provides a systematic process for gathering information about a broad picture and using it to establish a long-term trend and then translate that trend into specific goals and objectives (Poister, 2005). It mixes future thinking and objective analysis of goals and precedents that will chart the future course of actions that will ensure the long-term vitality and effectiveness of the organization (Poister \& Streib, 2005).

It can be said, in general terms, that the basis that called for theoretical and practical interest in the strategic planning process is the environmental uncertainty under which today's organizations live (Pearce et al, 1987) (Hendrick, 2003). That is, strategic planning is the systematic means to reduce the degree of uncertainty and risks associated with variables beyond the control of the management of the organization (Segars \& Grover, 1998). And developing long-term plans to direct the organization (Young, 2003). This was confirmed by Zomorrodian (2011), when he asserts that the importance of strategic planning stems from the fact that it helps focus the attention of the organization and its resources towards goals and strategies that will help it in growth, progress and adaptation in an environment in which change is the only constant.

The results of the controversy over the importance of strategic planning among theorists in the field of strategic management resulted in considering strategic planning as a success factor (Leontiades \& Tezel, 1980). And one of the main tools for management and managers (Nayga \& Baga, 1995) (Korosec, 2006). However, the results of a long series of studies to support the importance of strategic planning have yielded mixed results to support this. The importance of strategic planning has been questioned by (Leontiades \& Tezel, 1980). While the studies of (Armstrong, 1982), (Robinson \& Pearce, 1983), (Ramanjam \& Venkatraman, 1987), (Pearce et al, 1987), (Bracker et al, 1988), (Odom \& Boxx, 1988) (Sinha, 1990), (Kukalis, 1991), (Powell, 1992) Concluded for the conclusion that organizations that practice strategic planning excel. In addition to achieving the greatest success and the least failure in achieving its goals compared to those that do not practice it.

According to (Mara, 2002), strategic planning performs two functions: the first is to allocate scarce resources according to the requirements of the competitive environment, and the other is to enhance and strengthen the financial capacity of the organization. While the resources represent one of the important aspects of the performance of the organization (Eddleston et al, 2008). The organization's achievement of returns and a competitive advantage depends on the strategic planning used to enhance the leverage of these resources (Chrisman et al, 2003). As it helps the organization to properly utilize its resources, thus it improves its performance (Hamel \& Prahalad, 1989). The organization should manage its resources impactively and practice strategic planning in order to compete successfully in a competitive environment (Sirmon \& Hitt, 2003). More specifically, Zahra et al (2004) indicates that strategic planning multiplies the positive impact of creative capabilities on the organization's performance, as it helps the organization to correctly guess how to devote 
resources to a greater amount of creativity and risk tolerance. Therefore, practicing strategic planning more, should assist the organization in better integration and utilization of its resources to achieve competitive advantage (Ketokivi \& Castaner, 2004). Through its interactive nature and enabling the organization to respond to environmental changes, protecting its core technology by diagnosing and dealing with uncertainty situations (Fraser \& Stupak, 2002).

According to (GalBreath, 2010) the use of a single or unilateral scale to measure strategic planning is unlikely to capture the entire process and thus may fail for an accurate measurement. As well as research confirmation of the need for a multi-dimensional approach to frame and measure strategic planning (Veliyath \& Skortell, 1993). The process of measuring strategic planning is contextual (Dyson \& Foster, 1982). By following previous studies in the field of strategic planning that adopted a multi-dimensional perspective to measure strategic planning (Raman Jam et al, 1986), (Raman jam \& Venkatraman 1987), (Veliyath \& Shortell, 1993), (McKiernan \& Morris, 1994) (YasaiArdekani \& Haug, 1997), (Baker, 2003), Gal Breath, 2010). The current research will adopt the (Raman jam \& Venkatraman, 1987) (GalBreath, 2010) scale of distancing (external orientation, internal orientation, functional coverage, the resources provided for planning, and using the analytical tools), which the researcher will deal with in some detail as follows:

\subsubsection{External orientation}

The process of achieving compatibility between the organization and its environment is one of the issues that should be given adequate attention, and in this regard the literature indicated that strategic planning is the cornerstone of this harmony as it is one of the appropriate methods for correct interaction with the environment and achieving harmony between the organization and its environment (Ghezzi et al, 2010). It is designed to help the organization adapt to environmental changes (Laycock, 1990). Assessing opportunities and threats and assuming future conditions (Williams, 2002). Ansoff \& Sullivan, (1993) pointed out that the performance of an organization increases when its strategic behavior is in harmony with the environment. This was confirmed by (Thwaites \& Glaister, 1992). When it was reported that for the purpose of success in any field, the organization must choose a strategic pattern of behavior that is compatible with the level of environmental disturbance, and that the level of environmental complexity and the increase in the occurrence of changes requires an increase in the use of the environmental analysis process (external orientation) as one of the dimensions of the strategic planning process. The organization is required to perform an environmental analysis (Rhyne, 1985). For strategic success necessitates systematic external research with the aim of adapting to the environment (Javidan, 1984). The higher the level of environmental uncertainty, the more the organization can benefit from planning to deal with uncertainty situations (Armstrong, 1982), (Grant, 2003). By helping it anticipate and respond to changes, as well as focus its attention on prominent environmental trends and define their goals that will enhance their performance (Hoffman, 2007). And identifying environmental opportunities and threats (Hanson et al, 2016). And conforming to its potential (Hendrick, 2003). And enabling it to adapt to the requirements and pressures of the environment (Raman jam et al, 1987). And assisting the organization in detecting early warning signals, and gathering information that will help it to overcome responsive behavior and adopt proactive behavior that enables it to influence its environmental conditions (Ardekani \& Nystrom, 1996). Daft (2020) emphasized that by saying that the greater the level of uncertainty, the greater the need for the organization to planning to help it mitigate and mitigate negative influences and external transformations by assisting analysts in their survey of the environment, diagnosing potential moves and influencing the moves that can be taken by other organizations. As organizations strive to achieve positive results, and in their pursuit of these results, decision-makers and planners need information about business processes and the circumstances surrounding them, which can be obtained by surveying the organization's environment in a way that contributes to crystallizing a clear picture of the organization's position (Pickton \& Wright, 1998). This is because obtaining information about competitors, customers and 
stakeholders is the first step in understanding the environment of the organization (Hanson et al., 2016). Theorists in the field of strategic planning have indicated that an understanding of the environment is an essential element in formulating an organization's strategy (Lynch, 200o). The success of the organization in the merge and integration of the information obtained as a result of the environmental analysis process in the planning process will determine the level of strategic threats facing the organization (Rhyne, 1985). Moreover, the success of the organization will depend on the ability of managers to anticipate environmental changes and their understanding of the current and future implications of those changes (Bracker et al, 1988). Therefore, managers and through their reading of the environment (their external orientation) form their visions about it and then translate those visions into strategic and operational plans (Isabella \& Werddock, 1994).

\subsubsection{Internal orientation}

Strategic planning can be viewed as a process of insight into the future of the organization, which includes a systematic review and evaluation of tangible and intangible resources to set the series of future moves to be followed by the organization, as well as studying past performance, internal qualities and characteristics and assessing strengths and weaknesses (Williams, 2002). And its core capabilities and energies that can be mobilized to achieve its mission and deal with the opportunities and threats that the organization faces (Raman jam et al, 1986). And information about the organization's programs, resources, structure, and people (Wilkerson, 2007). Through the strategic planning process, the organization determines the precedents and then translates them into resource allocation plans. Thus, strategic planning becomes a guide to managing the reliability that finds horizontal and vertical diversity across organizational units and levels (Ketokivi \& Castaner, 2004). As the environment is in a state of constant change, the organization itself in terms of its resources and capabilities is the most stable basis on which to define the identity of the organization, and thus the diagnosis of what can be performed by the organization may provide a more reliable basis for the strategy.

\subsubsection{Functional coverage}

The commitment to planning and providing the financial and human resources it needs will enhance the monitoring capabilities of the organization, allowing it to extensively monitor competitive areas and provide useful information that can be used to develop strategic initiatives as well as confront the reactions and movements of competitors (Ardekani \& Haug, 1997). Understanding and supporting senior management is one of the most important success factors for the strategic planning process. For impactive action, strategic planning requires commitment on the part of those who will be affected by it (Armstrong, 1982). And wide participation by managers (Larsen et al, 2000). And that there is no idea of resistance to the planning process throughout the organization (Raman jam \& Venkatraman, 1987). It is described as a systematic problem-handling process characterized by the participation of multiple members (Hendrick, 2003). The fact that this will lead to increased partnership and commitment to the jointly found vision and mission (Wilkerson, 2007). Helping organizational members develop a common view of organizational goals (Ketokivi \& Castaner, 2004). In addition, the strategic planning process deals with long-term goals, something that requires the participation of top management (Hassan, 2010). Which may be psychological (the office space of the planning staff), intangible (the time spent by the CEO and other managers in the planning process) and financial (the invested capital) (Raman jam et al, 1986). To ensure that the organization achieves its goals, the commitment to use several inputs in the planning process may be necessary, as while the executive director and other managers form the basic inputs for the planning process, inputs and perspectives from several workers inside and outside the organization are necessary (GalBreath, 2010). 


\subsubsection{Resources provided}

The strategic planning process is uniquely designed to meet the unique and specific needs of the organization (Berry, 2007). Therefore, strategic planning requires an allocation of resources (Hassan, 2010). These resources may be psychological, intangible, and financial (Ramanjam et al, 1986). To ensure that the organization achieves its goals, the commitment to use several inputs in the planning process may be necessary, as while the executive director and other managers form the basic inputs for the planning process, inputs and perspectives from several workers inside and outside the organization are necessary (GalBreath, 2010).

\subsection{Competitiveness}

Competitiveness is a poorly defined concept (Porter, 1990). Since there is no agreement on a comprehensive and precise definition of it, the book disagrees about its content (Hickman, 1992). As a result, it means different things to different organizations (Feurer \& Chaharbaghi, 1994). Through a systematic review of the relevant literature, we attribute this disagreement to the difference in the concept of competitiveness according to the subject matter of discussion, whether it is an organization, industry or country (Buckley et al. 1988). And the difference in the quality of the approved indicators, whether they are partial or total, as well as the difference in the approach adopted by researchers in defining their concept (Emilian et al, 2009). The literature indicates that in the period from 1985 to 2006 more than 4000 research papers were published in scientific journals in various fields and disciplines and presented various concepts and indicators of competitiveness, which opens the way to a wide field of research related to defining a concept of competitiveness (Hong et al, 2008).

There are several approaches to the study of competitiveness produced by our review of the literature that can be identified in several entries. The first is the economic perspective that defines competitiveness as the ability of a country's producers to compete successfully in global markets (Treasury, 1983). Competitiveness may refer to a country's ability to produce, distribute, products or services in international markets with the aim of increasing returns compared to the resources used (Scott and Lodge, 1985). Others point out that it means the country's ability to sustain and expand its share in the international markets, while at the same time improving the standard of living of the country's citizens (Fajnzylber, 1988). the second approach as the function of the government, competitiveness is defined as the ability of the country to achieve the objectives of the central economic policy, especially in the area of growth in income and employment opportunities, without falling into the difficulties of the balance of payments (Fagerberg, 1988). It is also described as the country's ability to produce products and provide services that meet the requirements of international competition, while at the same time the citizens enjoy a high and sustainable standard of living (Krugman, 1994). Some researchers adopt a broad approach consisting of comparing macroeconomic performance and living standards with production trends (Durand et al, 1998). It is also known as the production of larger quantities and better quality of goods and services that are successfully marketed to consumers at home and abroad (Newall, 1992). the third approach, it blends the economic perspective, government functions, and sustainable development to define competitiveness as the ability of businesses, industries, regions, countries and global associations to be exposed to international competition in order to ensure a high return on production factors and high levels of the workforce on a sustainable basis (European Commission, 1994). its production growth and higher employment rates in a sustainable environment (OECD, 2000). The fourth approach is the ability to compete, which defines competitiveness as the ability of the organization to compete with other organizations in the market (Bruning and Lockshin, 1994). This approach describes it as the correct strategic positioning and reconciliation between the possibilities of operations that may affect the organization's ability to compete and its business performance 
(Andersen, 2004). It is the ability to innovate and adapt to changing economic conditions (Thierstein \& Abegg, 2002). The fifth approach is competitiveness as a synonym for the operational or productive capacity of the organization, the ability that the organization possesses at a certain time to resist its competitors, which is the ability to produce the right goods and services of good quality at the right price and at the right time, and this means meeting the needs of consumers more efficiently than other organizations (Oughton, 1997). It is the ability of the organization to provide products with quality, price and reasonable time and meet the requirements of customers in a more efficient and impactive manner compared to other organizations (Begg, 1999). It is also described as the organization's ability to permanently and profitably produce products that meet market requirements in terms of price and quality (Martin, 2005). It is the ability of the organization to design, produce and market superior products compared to those offered by competitors in light of price and non-price characteristics (Ajitabh \& Momaya, 2004). There is a final approach that considers competitiveness as a measure of the ability and performance of the organization in its markets and industry, and thus it is the organization's ability to work and interact through its financial capacity ( $\mathrm{Li}$ et al, 2009). A competitive organization is one that possesses a large growing market share, stable profits, and modern technology (Emilian et al 2009). It is the degree to which the organization is inclined to reveal and bridge the gaps between what the market desires and what is currently provided (Hult and Arrfelt, 2007).

Competitiveness is essential for the well-being of the citizens of any country, as it means growth of output and an increase in employment rates on a sustainable basis (Hong, 2008). As a result, good job opportunities are created, as well as the capital needed to provide sufficient infrastructure for service to the community. This research adopted the dimensions listed below to measure competitiveness:

\subsubsection{The strategy of the educational institution}

Strategic planning for education works to help educational institutions to take advantage of the strengths, reduce weaknesses, and direct decision-makers towards define the future features of the institution, thus making it easier for educational institutions to face challenges and keep pace with development. The university can translate the desired goals into programs and plans at the strategic levels through strategic planning, which prepares the educational institution as a system and allows the higher management to look at the institution and the relationships between its parts as a whole. A continuous planning process should be adopted in educational institutions that achieves the vision, mission and goals and is continuously evaluated, as well as the availability of data and information for strategic academic decision-makers and managing the institution in a different way that determines the gap between the current and future situation and draws the institution's strategic plans in light. The importance of the educational institution's strategy is that it provides the university's administration with its main thinking, which plays a major role in the formation and evaluation of each of the goals, plans and policies, as it enables it to anticipate some of the issues that may occur within it or in its external environment and to develop the necessary strategies to deal with them (National Institutional Accreditation Standards for Higher Education Institutions in Iraq, 2018).

\subsubsection{Governance and management}

University governance represents the ability of universities to achieve their goals, with a high level of quality, and improve their performance by following effective plans and appropriate methods through good governance. It is participation in decision-making by representatives of all beneficiaries of the university's services from students and local community. Governance is of great importance in universities, and its importance can be determined by the fact that it contributes to creating independent institutions that have boards and governing bodies responsible for determining the strategic direction for these institutions, ensuring the effectiveness of its management, and helping 
universities achieve their goals in the best possible way. ensuring a balance between long-term strategic responsibilities and short-term operational responsibilities, and helping to avoid administrative and financial corruption, and ensuring the rights and interests of workers from the administrative and academic bodies without discrimination. Governance contributes to the process of continuous improvement of the quality and performance of the institution as it is represented by a set of laws, systems and decisions that aim to achieve quality and excellence in performance by choosing appropriate and effective methods to achieve the plans and goals of the university. (National Institutional Accreditation Standards for Higher Education Institutions in Iraq, 2018).

\subsubsection{Financial and material resources}

The aspects of quality in the material facilities are represent in proportion to the nature of the educational process, and the development and satisfaction of the aesthetic aspect. The importance of material financial resources comes from the fact that they constitute the incubating environment for all activities and tasks that the academic institution carries out, including education, learning, scientific study, and community service, as well as the environment that sponsors human resources from students, academics, researchers, administrators and service employees. Therefore, the health and quality of this environment is from the foundations on which the university must develop efficient plans by guaranteeing, monitoring and continuous improvement, and implementing the procedures to ensure the implementation of these plans and monitoring them periodically, Perhaps one of the main criteria to ensure the safety and quality of the university environment is to ensure the availability of the necessary financial resources for this environment and its good management. The institution must also ensure a responsible and transparent financial management that follows the legally applicable financial procedures, and when considering the financial and human resources provided by the institution, it is not sufficient to study the adequacy of these sources, in terms of number and availability, but rather focus on their efficiency and expertise and employ that in achieving the tasks undertaken by educational institutions (National Institutional Accreditation Standards for Higher Education Institutions in Iraq, 2018).

\subsubsection{Faculty members}

The aspects of quality in the faculty members are represented in the diversity of the scientific level and background knowledge, their awareness of students' needs, regularity in the educational process, acceptance of feedback, work on developing intellectual skills, developing national sense and moral prudence, developing the analytical direction, developing an in-depth view, and its impacts on interaction personal. The interest in choosing faculty members is the decisive element in the success of the effectiveness of the teaching and learning process, and therefore the preparation and qualifications of the teaching staff must be sufficient to achieve the mission and goals of the educational institution, and the faculty members must be appointed according to academic rules and foundations that serve the institution's goals and development, and this requires the presence of regulations and instructions clarifying the responsibilities and duties of faculty members in terms of quorum according to academic titles, and providing appropriate facilities and support to attend conferences and workshops (National Institutional Accreditation Standards for Higher Education Institutions in Iraq, 2018).

\subsubsection{Students}

Students are considered the standard of the educational process, its fruits and the purpose of its existence, and preparing them to face life and its challenges in the present and future. Therefore, educational institutions work to provide students with skills, knowledge, information, methods of thinking, skills, and seek to formulate their conscience, refine their emotions and inculcate their 
values to conform to the standards of local and global citizenship. Developing an effective educational system that succeeds in preparing citizens who are able not only to absorb and adapt to these changes, but to lead and direct them towards building a productive, creative and prosperous society. This requires anticipating the future, drawing approximate expectations of what it will be, and planning to confront it by preparing students fortified with science, knowledge, thinking skills, emotional and emotional maturity, and practical and academic skills that enable them to succeed in different life paths (National Institutional Accreditation Standards for Higher Education Institutions in Iraq, 2018).

\subsubsection{Scientific research}

Scientific research is the backbone of universities which plays a fundamental role in development the universities. As the university's international standing depends on what it does to publish new, highquality research. This criterion is of great importance to the educational institution as it indicates the essence of its distinction. In the various scientific fields the salient feature, in terms of quantity and quality, the salient feature is that the scholarly scientific activity of scientific institutions, specifically directed towards scientific theoretical and applied discoveries by transforming them into pioneering projects, is the one that achieves the state of distinction, and the endeavor to attend conferences, seminars and workshops inside and outside the country by members of the teaching contributes to the continuous development of science and knowledge and the acquisition of skills through positive interaction with their peers in regional and international academic scientific institutions in order to achieve development sustainable human development (National Institutional Accreditation Standards for Higher Education Institutions in Iraq, 2018).

\subsubsection{Community service}

Universities derive their importance not only from their role in teaching and scientific study, but from their role in community service through serious influence in society through the development of study work, the formation of knowledge, its production and transfer to society in order to serve the human being and the citizen, and the nation. As the educational institution contributes to transmitting to new generations the experiences and knowledge of others and the standards and values that they have adopted, as it is a tool to preserve identity and heritage and transmit it from one generation to the next, and it has aesthetic and stimulating roles that allow graduates the opportunity to practice their experiences. Standard of focus for the educational institution through which faculty members, employees and students interact with all local and national community institutions in order to develop them economically, culturally, skillfully and socially in pursuit of integration between the educational institution and the community. The foundation must announce its activities; In addition to the participation of members of the local community within their boards of directors and to continuously follow up the view of the community components towards it, leading to the adoption of effective and appropriate strategies in order to work to improve its academic image and reputation (National Institutional Accreditation Standards for Higher Education Institutions in Iraq, 2018: 25).

\subsubsection{Curricula}

The attractive educational institution is the institution that provides quality educational programs, in order to prepare graduates who are always learning, with the aim of acquiring knowledge and preparing for life developments, self-realization and integration with others, as well as developing mental skills to solve problems and produce knowledge in an atmosphere dominated by fun and activity, and as it pays special attention with the cultivation of a set of high-end values among the learners. In this regard literature indicate that the quality aspects of the curriculum are represented 
in the degree of its coverage of basic topics, its proportionality with the student's comprehension ability, and relevance to practical reality. And familiarity with basic knowledge, as well as preparing the student for the era of globalization through learning a foreign language. Curricula is a tool for education in leading changes in society to prepare a quality of learners able to meet the requirements of the age and the future, so the curriculum as a science with its own rules and concepts, aims to build the human being within the framework of An integrated plan to provide appropriate educational experiences that lead to the learner's acquisition of the desired information, skills and attitudes for the comprehensive and integrated growth events of the learner. Therefore, it is important that the curricula meet the requirements of this renewal and change. Therefore, it is important to prepare and develop the curriculum based on specific standards that help build it according to solid scientific foundations that ensure the achievement of the goals for which it was set (National Institutional Accreditation Standards for Higher Education Institutions in Iraq, 2018).

\section{Methodology}

After 2003, Iraq witnessed comprehensive transformations in various fields in general, and higher education in particular, as the higher education sector witnessed several changes that brought it out of its local isolation to its openness to the world, Perhaps one of the most important of these transformations is the openness to the world in the field of education, and the increase in demand for higher education by members of society, believing in its vital economic and social importance, as well as the growing role of knowledge as a source of value generation. With these changes, many trends have emerged in the field of higher education, including the increase in the number of students enrolled in universities, the increase in the number of private universities that are synonymous with public education, as well as the large numbers of students studying abroad. In light of these transformations, it is no longer possible to face these challenges by traditional methods. Rather, new and advanced means should be sought to raise the level of university education, including concern for the quality of education and reliance on international standards of excellence to ensure the quality of education and recognition of the certificates granted by universities. As researchers refer to the decline in the level of Iraqi universities, and this is due to a number of reasons, including the central education system, teaching methods, curricula, and the inefficiency of some departments of these institutions, which reflected negatively on the level of classification and competitiveness of these universities. There is no doubt that the exit of most Iraqi universities from international rankings and their late ranking, is an indication of the need to reconsider the conditions of universities. Therefore, the research problem can be identified by the following main questions: What is the impact of strategic planning on the competitiveness of Iraqi universities according to the national institutional accreditation standards of the Iraqi Ministry of Higher Education and Scientific Research?

The research stems its importance through the following:

1. The research is an attempt to diagnose the reality of strategic planning and competitiveness in the researched university.

2. The research tries to highlight the importance of its dimension in the field of the researched university, which plays an important role in developing the capabilities of institutions working in this sector.

3. The research contributes to forming a basis and a knowledge and application framework that stems from the assumption that successful universities are those that have the ability to achieve compatibility between their competitive strategies and the requirements of the customer. Focusing on the customer is the basis and the driving force behind the term of strategic planning and then is reflected in the university's competitiveness.

4. Although strategic planning has been saturated with research by theorists, its decision on the practical level is still a stand-alone problem, especially in Iraq. Thus, the research stems its importance from its endeavor to provide some field evidence on the impact of strategic 
planning in an important sector, namely education, which plays a vital role in society.

The research attempt to achieve the following objectives:

1. diagnose the reality of strategic planning and competitiveness in the researched university.

2. highlight the importance of its dimension in the field of the researched university, which plays an important role in developing the capabilities of institutions working in this sector.

3. forming a basis and a knowledge and application framework that stems from the assumption that successful universities are those that have the ability to achieve compatibility between their competitive strategies and the requirements of the customer.

4. the research stems its importance from its endeavor to provide some field evidence on the impact of strategic planning in university's competitiveness, with special reference to Iraq.

5. Test the impact models between strategic planning and university's competitiveness.

The research attempts to test the main hypothesis which is: There is a significant impact for the strategic planning in university's competitiveness.

The research community spread over 300 participants work in University of Technology, Baghdad, Iraq. $\mathrm{N}>50+8 \mathrm{~m}$ is an equation that can use to estimate the appropriate sample size (Green,1991). By applying the equation, the researchers discovered that the needed sample size was expected to be at least (82) participants, so they distribute over (200) questionnaires, and only (158) of them were valid for analysis.

The data for this research was gathered through a questionnaire. The validity and reliability of the questionnaires were checked, and table 1 shows the result of internal consistency. The questionnaire of this research comprises three parts, The study sample's demographic data is covered in section I, Part II covered strategic planning dimensions, which comprises 20 questions on external orientation, internal orientation, functional coverage, resources provided, which consists (5) questions for each of them (Galbreath, 2010). And the III part dealt with the university's competitiveness which consists of 40 questions on the strategy of the educational institution, governance and management, financial and material resources, faculty members, students, scientific research, community service, curricula, which consists (5) questions for each of them (National Institutional Accreditation Standards for Higher Education Institutions in Iraq, 2018). The research employs the Likert Scale, a five-point rating scale. The participants in the research were 90 men $(57 \%)$ and 68 women (43\%). The average age of the participants was 45 (30-34), (28 percent), 52 (3539) ( 32 percent). 40 (40-45), ( 26 percent), 21 (50 and above), ( 14 percent). The proportion of the participants with doctorates, master's, and diploma degree was 55 (34 percent), 8o (50 percent), 23 (16 percent) respectively.

Table 1: Internal consistency indicators for research dimensions

\begin{tabular}{|l|c|}
\hline the dimensions & coefficient of cronbach's alpha \\
\hline External orientation & 0.85 \\
\hline Internal orientation & 0.79 \\
\hline Functional coverage & 0.86 \\
\hline Resources provided & 0.81 \\
\hline Total Strategic planning & 0.93 \\
\hline The strategy of the educational institution & 0.70 \\
\hline Governance and management & 0.71 \\
\hline Financial and material resources & 0.78 \\
\hline Faculty members & 0.87 \\
\hline Students & 0.83 \\
\hline Scientific research & 0.84 \\
\hline Community service & 0.84 \\
\hline Curricula & 0.86 \\
\hline Total university's Competitiveness & 0.87 \\
\hline Total questionnaire & 0.94 \\
\hline
\end{tabular}




\section{Results}

\subsection{Structural Equation Modeling}

The structural modeling equation is well-known and commonly used in management science (Moutinho and Hutcheson, 2011). Since it gives researchers a thorough tool for evaluating and modifying theoretical models, as a result, there is a lot of potential for furthering the theory's development (Whitman, and Woszczynski, 2004). As a result, the researchers used confirmatory factor analysis to ensure that all research dimensions had adequate and discriminant validity. Table 2 shows the model's indicators of strategic planning, university competitiveness, which indicates that the models obtained good values according to the confirmatory factor analysis, which means that the researchers' model can be accepted.

Table 2: Indicators of Confirmatory Factor Analysis for Research Dimensions

\begin{tabular}{|l|c|c|}
\hline indicators & Strategic planning & university's Competitiveness \\
\hline $\mathrm{X}^{2}$ & 2.56 & 2.00 \\
\hline Root Mean Square Error of Approximation & 0.10 & 0.08 \\
\hline goodness of fit index & 0.80 & 0.69 \\
\hline The normed fit index & 0.78 & 0.64 \\
\hline The comparative fit index & 0.85 & 0.77 \\
\hline Adjusted Goodness of Fit Index & 0.74 & 0.65 \\
\hline Tucker-Lewis index & 0.83 & 0.75 \\
\hline Incremental Fit Index & 0.85 & 0.78 \\
\hline
\end{tabular}

Tables (3) and (4) show that model estimations are smaller than 0.01 and critical ratio values are larger than (1.96). This supports the assumption that vertebrae of every dimension are capable of measurement. This indicates the validity of the hypothesis that the vertebrae of each variable are capable of measuring, and it meets the greater or equivalent (o.40) condition, i.e., a minimum acceptance rate is 0.40 (Costello \& Osborne, 2005).

Table 3: Strategic Planning dimensions Estimates $n=158$

\begin{tabular}{|c|c|c|c|c|c|c|c|}
\hline & & & Estimates & Standard error & critical ratio & P. value & Label \\
\hline VAR1 & $\begin{array}{l}<-- \\
\end{array}$ & $F_{1}$ & 1.000 & & & & \\
\hline VAR2 & $<---$ & $\mathrm{F}_{1}$ & 0.969 & 0.098 & 9.852 & $* * *$ & Par-1 \\
\hline $\mathrm{VAR}_{3}$ & <--- & $F_{1}$ & 0.810 & 0.097 & 8.386 & $* * *$ & Par-2 \\
\hline $\mathrm{VAR}_{4}$ & $<---$ & $\mathrm{F}_{1}$ & 0.788 & 0.090 & 8.793 & $* * *$ & Par-3 \\
\hline VAR5 & $<---$ & $\mathrm{F}_{1}$ & 0.906 & 0.096 & 9.471 & $* * *$ & Par-4 \\
\hline VAR1o & $<---$ & $\mathrm{F}_{2}$ & 1.000 & & & & \\
\hline VAR9 & $<---$ & $\mathrm{F}_{2}$ & 1.487 & 0.180 & 8.273 & $* * *$ & Par-5 \\
\hline VAR8 & $<---$ & $\mathrm{F}_{2}$ & 1.071 & 0.176 & 6.091 & $* * *$ & Par-6 \\
\hline VAR7 & $<---$ & $\mathrm{F}_{2}$ & 0.909 & 0.126 & 7.205 & $* * *$ & Par-7 \\
\hline VAR6 & $<---$ & $\mathrm{F}_{2}$ & 0.846 & 0.137 & 6.186 & $* * *$ & Par-8 \\
\hline VAR16 & $<---$ & $\mathrm{F}_{3}$ & 1.000 & & & & \\
\hline VAR17 & $<---$ & $\mathrm{F}_{3}$ & 0.948 & 0.121 & 7.859 & $* * *$ & Par-9 \\
\hline VAR18 & $<---$ & $\mathrm{F}_{3}$ & 1.004 & 0.108 & 9.298 & $* * *$ & Par-10 \\
\hline VAR19 & $<---$ & $F_{3}$ & 0.953 & 0.109 & 8.726 & $* * *$ & Par-11 \\
\hline VAR2o & $<---$ & $\mathrm{F}_{3}$ & 0.565 & 0.094 & 5.980 & $* * *$ & Par-12 \\
\hline VAR11 & $<---$ & $\mathrm{F}_{4}$ & 1.000 & & & & \\
\hline VAR12 & $<---$ & $\mathrm{F}_{4}$ & 1.133 & 0.132 & 8.593 & $* * *$ & Par-13 \\
\hline VAR13 & $<---$ & $\mathrm{F}_{4}$ & 1.174 & 0.122 & 9.660 & $* * *$ & Par-14 \\
\hline VAR14 & $<---$ & $\mathrm{F}_{4}$ & 1.092 & 0.112 & 9.710 & $* * *$ & Par-15 \\
\hline VAR15 & $<---$ & $\mathrm{F}_{4}$ & 0.918 & 0.114 & 8.050 & $* * *$ & Par-16 \\
\hline
\end{tabular}


Table 4: University's Competitiveness dimensions Estimates $n=158$

\begin{tabular}{|c|c|c|c|c|c|c|c|}
\hline & & & Estimates & Standard error & critical ratio & P.Vale & Label \\
\hline VAR21 & $<<--$ & $\mathrm{F}_{1}$ & 1.000 & & & & \\
\hline VAR22 & $<---$ & $F_{1}$ & 1.066 & 0.241 & 4.429 & $* * *$ & Par-1 \\
\hline VAR23 & $<---$ & $F_{1}$ & 1.385 & 0.301 & 4.603 & *** & Par-2 \\
\hline VAR24 & $<---$ & $\mathrm{F}_{1}$ & 1.835 & 0.354 & 5.179 & $* * *$ & Par-3 \\
\hline $\mathrm{VAR}_{25}$ & $<---$ & $F_{1}$ & 1.249 & 0.252 & 4.962 & $* * *$ & Par-4 \\
\hline VAR26 & $<---$ & $\mathrm{F}_{2}$ & 1.000 & & & & \\
\hline VAR27 & $<---$ & $\mathrm{F}_{2}$ & .796 & 0.135 & 5.912 & $* * *$ & Par-5 \\
\hline VAR28 & $<---$ & $\mathrm{F}_{2}$ & .852 & 0.132 & 6.438 & $* * *$ & Par-6 \\
\hline VAR29 & $<---$ & $\mathrm{F}_{2}$ & .529 & 0.125 & 4.234 & $* * *$ & Par-7 \\
\hline VAR3o & $<---$ & $\mathrm{F}_{2}$ & .643 & 0.118 & 5.428 & $* * *$ & Par-8 \\
\hline $\mathrm{VAR}_{31}$ & $<---$ & $\mathrm{F}_{3}$ & 1.000 & & & & \\
\hline $\mathrm{VAR}_{32}$ & $<---$ & $F_{3}$ & 1.123 & 0.166 & 6.774 & $* * *$ & Par-9 \\
\hline $\operatorname{VAR}_{33}$ & $<---$ & $\mathrm{F}_{3}$ & 0.803 & 0.153 & 5.262 & $* * *$ & Par-10 \\
\hline $\mathrm{VAR}_{34}$ & $<---$ & $\mathrm{F}_{3}$ & 0.710 & 0.168 & 4.221 & $* * *$ & Par-11 \\
\hline $\mathrm{VAR}_{35}$ & $<---$ & $\mathrm{F}_{3}$ & 0.887 & 0.144 & 6.154 & $* * *$ & Par-12 \\
\hline $\mathrm{VAR}_{3} 6$ & $<---$ & $\mathrm{F}_{4}$ & 1.000 & & & & \\
\hline $\mathrm{VAR}_{37}$ & $<---$ & $\mathrm{F}_{4}$ & 1.088 & 0.141 & 7.704 & $* * *$ & Par-13 \\
\hline $\mathrm{VAR}_{3} 8$ & $<---$ & $\mathrm{F}_{4}$ & 0.692 & 0.100 & 6.950 & $* * *$ & Par-14 \\
\hline $\mathrm{VAR}_{39}$ & $<---$ & $\mathrm{F}_{4}$ & 1.151 & 0.134 & 8.560 & $* * *$ & Par-15 \\
\hline VAR4o & $<---$ & $\mathrm{F}_{4}$ & 0.892 & 0.123 & 7.230 & $* * *$ & Par-16 \\
\hline $\mathrm{VAR}_{41}$ & $<---$ & $\mathrm{F}_{5}$ & 1.000 & & & & \\
\hline $\mathrm{VAR}_{42}$ & $<---$ & $\mathrm{F}_{5}$ & 0.857 & 0.089 & 9.625 & $* * *$ & Par-17 \\
\hline VAR $43_{3}$ & $<---$ & $\mathrm{F}_{5}$ & 1.014 & 0.101 & 10.049 & $* * *$ & Par-18 \\
\hline VAR44 & $<---$ & $\mathrm{F}_{5}$ & 1.005 & 0.103 & 9.719 & $* * *$ & Par-19 \\
\hline VAR 45 & $<---$ & $\mathrm{F}_{5}$ & 0.954 & 0.100 & 9.574 & $* * *$ & Par-20 \\
\hline VAR46 & $<---$ & F6 & 1.000 & & & & \\
\hline VAR47 & $<---$ & F6 & 1.245 & 0.183 & 6.801 & $* * *$ & Par-21 \\
\hline $\mathrm{VAR}_{4} 8$ & $<---$ & F6 & 1.224 & 0.172 & 7.117 & $* * *$ & Par-22 \\
\hline VAR49 & $<---$ & F6 & 1.156 & 0.159 & 7.262 & $* * *$ & Par-23 \\
\hline VAR $_{50}$ & $<---$ & F6 & 1.258 & 0.167 & 7.545 & $* * *$ & Par-24 \\
\hline VAR $_{51}$ & $<---$ & $\mathrm{F}_{7}$ & 1.000 & & & & \\
\hline VAR $_{52}$ & $<---$ & $\mathrm{F}_{7}$ & 1.130 & 0.131 & 8.595 & $* * *$ & Par-25 \\
\hline VAR $_{53}$ & $<---$ & $\mathrm{F}_{7}$ & 1.025 & 0.126 & 8.151 & $* * *$ & Par-26 \\
\hline VAR $_{54}$ & $<---$ & $\mathrm{F}_{7}$ & 0.889 & 0.101 & 8.765 & $* * *$ & Par-27 \\
\hline VAR55 & $<---$ & $\mathrm{F}_{7}$ & 1.100 & 0.118 & 9.326 & $* * *$ & Par-28 \\
\hline VAR6o & $<---$ & F8 & 1.000 & & & & \\
\hline VAR59 & $<---$ & F8 & 1.035 & 0.110 & 9.403 & $* * *$ & Par-29 \\
\hline $\mathrm{VAR}_{5} 8$ & $<---$ & F8 & 0.511 & 0.071 & 7.245 & $* * *$ & Par-30 \\
\hline VAR $_{57}$ & $<---$ & F8 & 1.032 & 0.091 & 11.327 & $* * *$ & Par-31 \\
\hline VAR $_{5} 6$ & $<---$ & F8 & 0.797 & 0.083 & 9.631 & $* * *$ & Par-32 \\
\hline
\end{tabular}

\subsection{Descriptive Analysis of the Research Dimensions}

The values in table 5 represent the mean, standard deviations, and coefficients of correlation of research dimensions, on the overall level, the mean of research dimensions reach (3.69) (3.91) of strategic planning and university's competitiveness respectively, which is high value, The high 
harmony in the sample's responses was confirmed, by the standard deviation value which reaches (o.57) (0.47) respectively. Table 5 shows the descriptive analysis at the sub-dimensions level., Table 5 also shows the coefficients of correlation between the research dimensions sub-dimensions, which indicates the validity of scale construction since all strategic planning sub-dimensions are significantly correlated.

Table 5: The Descriptive Analysis \& The Coefficients of Correlation Between Research Dimensions $\mathrm{n}=158$

\begin{tabular}{|c|c|c|c|c|c|c|c|c|c|c|c|c|c|c|c|c|}
\hline Dimensions & Mean & Std.Dev. & 1 & 2 & 3 & 4 & 5 & 6 & 7 & 8 & 9 & 10 & 11 & 12 & 13 & 14 \\
\hline External orientation & 3.74 & 0.79 & 1 & & & & & & & & & & & & & \\
\hline Internal orientation & 3.55 & 0.81 & $.70^{*}$ & 1 & & & & & & & & & & & & \\
\hline Functional coverage & 3.44 & 0.89 & $.71^{\mathrm{N}}$ & .74 & 1 & & & & & & & & & & & \\
\hline Resources provided & 3.63 & 0.81 & $.63^{*}$ & $.69^{*}$ & $.77^{*}$ & 1 & & & & & & & & & & \\
\hline Total Strategic planning & 3.59 & 0.73 & .85 & $.88^{\prime}$ & .91 & .87 & 1 & & & & & & & & & \\
\hline The strategy of the educational institution & 3.63 & 0.73 & $.53^{* x^{*}}$ & .49 & $.58^{* x+2}$ & $.58^{*}$ & $.62^{*}$ & 1 & & & & & & & & \\
\hline Governance and management & 3.88 & 0.55 & $.32^{* *}$ & $.44^{*}$ & $.41^{* *}$ & $.46^{*}$ & $.46^{*}$ & $.56^{*}$ & 1 & & & & & & & \\
\hline Financial and material resources & 3.86 & 0.54 & .40 & .53 & .53 & .52 & .56 & $.46^{\prime \prime}$ & $.53^{\pi}$ & 1 & & & & & & \\
\hline Faculty members & 3.79 & 0.60 & $.51^{k x}$ & $.56^{*}$ & $.60^{*}$ & .64 & $.66^{*}$ & .61 & $.53^{*}$ & $.64^{*}$ & 1 & & & & & \\
\hline Students & 4.10 & 0.59 & $.33^{\prime \prime}$ & $.43^{n+1}$ & .39 & $.41^{3}$ & $.44^{\pi}$ & $.38^{\prime \prime}$ & $.33^{\prime \prime}$ & .55 & $.56^{\prime \prime}$ & 1 & & & & \\
\hline Scientific research & 4.02 & 0.62 & .29 & $.43^{* x+x}$ & .39 & .34 & $.41^{*}$ & .38 & $.38^{* x}$ & .52 & .54 & $.69^{*}$ & 1 & & & \\
\hline Community service & 4.01 & 0.61 & $.26^{*}$ & $.38^{x+2}$ & .35 & $.33^{*}$ & $.37^{*}$ & $.43^{*}$ & $.32^{* 4}$ & $.55^{* *}$ & .54 & $.65^{*}$ & $.64^{*}$ & 1 & & \\
\hline Curricula & 4.00 & 0.64 & .26 & .41 & .37 & $.32^{*}$ & .39 & .47 & .35 & $.49^{n+1}$ & .50 & $.65^{*+1}$ & $.71^{14}$ & $.73^{\prime \prime}$ & 1 & \\
\hline Total university's Competitiveness & 3.91 & 0.47 & $.48^{* x}$ & $.60^{* * *}$ & .59 & $.59^{*}$ & $.64^{*}$ & $.71^{*}$ & $.65^{*}$ & $.76^{* * 4}$ & $.80^{* * x}$ & $.78^{* * x}$ & $.79^{*}$ & $.79^{*}$ & $.80^{* * 3}$ & \\
\hline
\end{tabular}

\subsection{Impact of Strategic Planning on University's Competitiveness}

The results of the test of impact models are shown in table 6, the significant impact of strategic planning on a university's competitiveness, The F value is 112.08, which indicates a high level of significance, the value of $\mathrm{R}$ squared which is 0.41 , indicates that this model had a high explanatory value. This value means that strategic planning explains $41 \%$ of the changes in the university's competitiveness. The impact model's simple regression equation between the strategic planning and university's competitiveness was as follows:

University's Competitiveness $=(\alpha)+(\beta)$ Strategic planning

University's Competitiveness $=(2.42)+(0.64)$

Table 6: Analytical indicators of the impact of strategic planning in university's Competitiveness

\begin{tabular}{|l|c|c|c|c|c|c|}
\hline Dimension & $\boldsymbol{\beta}$ & $\alpha$ & $\mathrm{R}^{2}$ & $\mathrm{P}$ & $\mathrm{df}$ & $\mathrm{f}$ \\
\hline Strategic planning & 0.64 & 2.42 & 0.41 & 0.000 & 157 & 112.08 \\
\hline
\end{tabular}

At the macro level, the above findings support the hypothesis that strategic planning has a significant impact on the university's competitiveness. Table 7 summarizes results of the impact model test on the level of sub-dimensions:

1. External Orientation: This dimension impact significantly on the competitiveness of the university. The value of calculated $\mathrm{F}$ is 47.38 which is higher compared to the tabular value. the value of $\mathrm{R}$ squared which is 0.23 , indicates that external orientation explains $23 \%$ of the changes in university's Competitiveness. The $\beta$ value which is 0.48 means that the changes in external orientation in one unit would result in changes in the Competitiveness of the university by $48 \%$. The first sub-hypothesis which is (the external orientation impact significantly on the university's Competitiveness) can be accepted based on these findings.

2. Internal Orientation: This dimension impact significantly on the competitiveness of the university. The value of calculated F is 90.40 which is higher compared to the tabular value. 
the value of $\mathrm{R}$ squared which is 0.36 , indicates that internal orientation explains $36 \%$ of the changes in university's Competitiveness. The $\beta$ value which is o.6o means that the changes in internal orientation in one unit would result in changes in the Competitiveness of the university by $60 \%$. The second sub-hypothesis which is (the internal orientation impact significantly on the university's Competitiveness).

3. Functional Coverage: This dimension impact significantly on the competitiveness of the university. The value of calculated $\mathrm{F}$ is 87.41 which is higher compared to the tabular value. the value of $R$ squared which is 0.35 , indicates that functional coverage explains $35 \%$ of the changes in university's Competitiveness. The $\beta$ value which is 0.59 means that the changes in functional coverage in one unit would result in changes in the Competitiveness of the university by $59 \%$. The third sub-hypothesis which is (the functional coverage impact significantly on the university's Competitiveness).

4. Resources provided: This dimension impact significantly on the competitiveness of the university. The value of calculated $\mathrm{F}$ is 86.04 which is higher compared to the tabular value. the value of $\mathrm{R}$ squared which is 0.35 , indicates that the resources provided explain $35 \%$ of the changes in the university's Competitiveness, the $\beta$ value which is 0.59 means that the changes in resources provided in one unit would result in changes in the Competitiveness of the university by $59 \%$. The fourth sub-hypothesis which is (the resources provided impact significantly on the university's Competitiveness).

Table 7: Analytical indicators of the impact of Strategic Planning dimensions on university's Competitiveness

\begin{tabular}{|l|c|c|c|c|c|c|}
\hline dimensions & $\beta$ & $\alpha$ & $\mathrm{R} 2$ & $\mathrm{P}$ & $\mathrm{df}$ & $\mathrm{f}$ \\
\hline external orientation & 0.48 & 2.84 & 0.23 & 0.000 & 157 & 47.38 \\
\hline internal orientation & 0.60 & 2.67 & 0.36 & 0.000 & 157 & 90.40 \\
\hline functional coverage & 0.59 & 2.82 & 0.35 & 0.000 & 157 & 87.41 \\
\hline the use of analytical tools & 0.59 & 2.66 & 0.35 & 0.000 & 157 & 86.04 \\
\hline
\end{tabular}

\section{Discussion and Interpretation}

The research aimed to explore the impact of strategic planning in the competitiveness. The fundamental impetus for this research is a new set of concerns that university administrators are experiencing. Universities' administrations are particularly concerned about the impacts of multidimensional rivals and the saturation of important market niches, the external environment's volatility, the need to meet customer demands, as well as the requirement to compete in an increasingly competitive market, and the need to be inventive which have an impact on overall performance. The conclusions of this research can help university officials make better decisions.

This research's conclusions have three major implications for university administration:

1. Universities that want to improve their competitiveness should have a formalized strategic planning process and strategic philosophy. Universities' administrations must build surveillance tools capable of interpreting environmental changes. At the university level, it is necessary to be able to react swiftly to changes in the environment (both external and internal). Of course, this necessitates dedication to environmental research.

2. Universities must take a long-term approach to resource allocation to achieve higher levels of performance. These resources could be psychological, intangible, or monetary in nature. The ability to create a unique performance that meets customers' wants is critical. One of the most essential success criteria for obtaining unique performance is commitment and supporting university administration for strategic planning. The findings of this research imply that high-performing universities are committed to strategic planning and have support for it. 
3. Strategic planning with a high level of functional coverage enhances strategic planning efficacy and overall performance. strategic planning relies on a thorough grasp of the many functional areas, as well as an awareness of the organization and its capabilities, to put recommended ideas into action. This implies that functional coverage is a vital component of effective strategic planning that leads to competitiveness, as one of the research's findings suggests.

This research's conclusions are limited to Iraqi universities in general, and the university of technology in particular. As a result, future research with a more comprehensive sample in a different context could yield various results. Furthermore, because the strategic planning dimensions identified in this research may be not exhaustive, identify best dimensions could represent area for future research.

\section{Conclusions}

1. It appeared that the change in the external approach taken by the university, represented by the interest in environmental issues in a holistic manner, especially in the field of analyzing environmental, societal, technology, competitiveness, and customers issues, was reflected in the effect of further improvement in the university's competitiveness.

2. It found that the university has invested in analyzing internal capabilities, employee issues, the effectiveness of operations, strengths and weaknesses, past performance, and the causes of past failures, as well as analyzing the interests of stakeholders to introduce more changes in its efforts to improve its competitiveness.

3. The university's tendency to employ its functional areas to improve its competitiveness is evident, and this is evident in the field of investment and employment of the job capabilities of marketing, finance, information technology, research and development, and customer service to improve its competitiveness.

4. It seems that there is a clear tendency for the university towards achieving a state of integration between its functional areas to bring about more change in its competitiveness, and among the forms of that integration is the exchange of the university units for their material and moral resources and the use of inputs from different individuals within the organization as well as the use of external experts to improve the competitiveness of the university.

\section{Recommendations}

1. The university should pay attention to environmental issues in a holistic manner, especially in the field of analyzing environmental and societal, technology, competitiveness, and customer issues to improve its competitiveness.

2. The university should invest in the analysis of internal capabilities, employee issues, the effectiveness of operations, strengths, weaknesses, past performance, and causes of past failures, as well as analyzing the interests of stakeholders to bring about more changes in its efforts to improve its competitiveness.

3. The university should employ its functional fields to improve its competitiveness, by investing and employing the capabilities of the marketing, finance, information technology, research and development, and customer service function to improve its competitiveness.

4. The university must achieve a state of integration between its functional areas to bring about a further change in its competitiveness, by exchanging the university units for its material and moral resources and using inputs from different individuals within the organization, and using external experts to improve its competitiveness. 


\section{References}

Ajitabh, A., \& Momaya, K. (2004). Competitiveness of firms: review of theory, frameworks and models. Singapore management review, 26(1), 45-61.

Andersen, T. J. (2004). Integrating decentralized strategy making and strategic planning processes in dynamic environments. Journal of management studies, 41(8), 1271-1299.

Ansoff, H. I., \& Sullivan, P. A. (1993). Optimizing profitability in turbulent environments: A formula for strategic success. Long range planning, 26(5), 11-23.

Armstrong, J. S. (1982). The value of formal planning for strategic decisions: Review of empirical research. Strategic management journal, 3(3), 197-211.

Baker, G. A. (2003). Strategic planning and financial performance in the food processing sector. Review of Agricultural Economics, 25(2), 470-482.

Bdair, R. R. (2011). Transportation Strategic Planning Under Uncertainty: The Palestinian Case (Doctoral dissertation).

Begg, I. (1999). Cities and competitiveness. Urban studies, 36(5-6), 795-809.

Berry, F. S., \& Wechsler, B. (1995). State agencies' experience with strategic planning: Findings from a national survey. Public administration review, 159-168.

Berry, F. S. (2007). Strategic planning as a tool for managing organizational change. International Journal of Public Administration, 30(3), 331-346.

Bracker, J. S., Keats, B. W., \& Pearson, J. N. (1988). Planning and financial performance among small firms in a growth industry. Strategic management journal, 9(6), 591-603.

Bruning, E. R., \& Lockshin, L. S. (1994). Marketing's role in generating organizational competitiveness. Journal of Strategic Marketing, 2(3), 163-188.

Buckley, P. J., Pass, C. L., \& Prescott, K. (1988). Measures of international competitiveness: a critical survey. Journal of marketing management, 4(2), 175-200.

Derto, S. C. (1997). Modern Management: Diversity, Quality, Ethics, and the Global Environment. Prentice Hall.

Chrisman, J. J., Chua, J. H., \& Zahra, S. A. (2003). Creating wealth in family firms through managing resources: Comments and extensions. Entrepreneurship theory and practice, 27(4), 359-365.

Costello, A. B., \& Osborne, J. (2005). Best practices in exploratory factor analysis: Four recommendations for getting the most from your analysis. Practical assessment, research, and evaluation, 10(1), 7.

Daft, R. L. (2020). Organization theory \& design. Cengage learning.

Durand, M., Madaschi, C., \& Terribile, F. (1998). Trends in OECD countries' international competitiveness: The influence of emerging market economies.

Dutton, J. E., \& Duncan, R. B. (1987). The influence of the strategic planning process on strategic change. Strategic management journal, 8(2), 103-116.

Dyson, R. G., \& Foster, M. J. (1982). The relationship of participation and effectiveness in strategic planning. Strategic management journal, 3(1), 77-88.

Eddleston, K. A., Kellermanns, F. W., \& Sarathy, R. (2008). Resource configuration in family firms: Linking resources, strategic planning and technological opportunities to performance. Journal of Management Studies, 45(1), 26-50.

Emilian, R., Elena, C., Lavinia, M., \& Brînduşoiu, C. N. (2009). Hospetitiveness-the empirical model of competitiveness in Romanian hospitality industry. Amfiteatru Economic, 11(26), 461-472.

European Commission (1994) Competitiveness Advisory Group, Enhancing European Competitiveness, 2nd Report to The President of The Commission, OOPEC: Luxembourg.

Fagerberg, J. (1988). International competitiveness. The economic journal, 98(391), 355-374.

Fajnzylber, F. (1988). International competitiveness: agreed goal, hard task. Cepal Review.

Feurer, R., \& Chaharbaghi, K. (1994). Defining competitiveness: a holistic approach. Management decision.

Fraser, D. L., \& Stupak, R. J. (2002). A synthesis of the strategic planning process with the principles of andragogy: learning, leading, and linking. International Journal of Public Administration, 25(9-10), 1199-1220.

Galbreath, J. (2010). Drivers of corporate social responsibility: The role of formal strategic planning and firm culture. British Journal of Management, 21(2), 511-525.

Ghezzi, A., Balocco, R., \& Rangone, A. (2010). How to get strategic planning and business model design wrong: the case of a mobile technology provider. Strategic Change, 19(5-6), 213-238.

Grant, R. M. (2003). Strategic planning in a turbulent environment: Evidence from the oil majors. Strategic management journal, 24(6), 491-517.

Green, S. B. (1991). How many subjects does it take to do a regression analysis. Multivariate behavioral research, 26(3), 499-510. 
Hamel, G., \& Prahalad, C. (1989). Strategic intent, harvard business rewiev. Tekst dostupan na: http://hbr. org/1989/05/strategic-intent/ar/(25. oktobar 2012. godine), 1-101.

Hassan, H. (2010). The relationship between firms' strategic orientations and strategic planning process. International Journal of Business and Management, 5(11), 35.

Hendrick, R. (2003). Strategic planning environment, process, and performance in public agencies: A comparative study of departments in Milwaukee. Journal of Public Administration Research and Theory, 13(4), 491-519.

Li, H., Li, V., Skitmore, M., Wong, J. K. W., \& Cheng, E. W. (2009). Competitiveness factors: a study of the real estate market in China. Construction Management and Economics, 27(6), 567-579.

Hickman, B. G. (Ed.). (1992). International productivity and competitiveness. Oxford University Press on Demand.

Treasury, H. M. S. (1983). International Competitiveness, Economic Progress Report.

Hanson, D., Hitt, M. A., Ireland, R. D., \& Hoskisson, R. E. (2016). Strategic management: Competitiveness and globalisation. Cengage AU.

Hoffman, R. C. (2007). The strategic planning process and performance relationship: does culture matter?. Journal of Business Strategies, 24(1).

Hong, S. W. C. (2008). Competitiveness in the tourism sector: a comprehensive approach from Economic and Management points. Springer Science \& Business Media.

Hult, G. T. M., Ketchen, D. J., \& Arrfelt, M. (2007). Strategic supply chain management: Improving performance through a culture of competitiveness and knowledge development. Strategic management journal, 28(10), $1035-1052$.

Isabella, L. A., \& Waddock, S. A. (1994). Top management team certainty: Environmental assessments, teamwork, and performance implications. Journal of Management, 20(4), 835-858.

Javidan, M. (1984). Research note and communication. The impact of environmental uncertainty on long-range planning practices of the US savings and loan industry. Strategic Management Journal, 5(4), $381-392$.

Ketokivi, M., \& Castaner, X. (2004). Strategic planning as an integrative device. Administrative Science Quarterly, 49(3), 337-365.

Korosec, R. L. (2006). Is department-based strategic planning more effective than organization-wide strategic planning?: Empirical evidence from senior managers. Public Performance \& Management Review, 30(2), 221244 .

Armstrong, G., Adam, S., Denize, S., \& Kotler, P. (2014). Principles of marketing. Pearson Australia.

Kriemadis, T., \& Theakou, E. (2007). Strategic Planning Models in Public and Non-Profit Sport Organizations. Choregia, 3(2).

Krugman, P. (1994). Competitiveness: a dangerous obsession. Foreign Aff., 73, 28.

Kukalis, S. (1991). Determinants of strategic planning systems in large organizations: A contingency approach. Journal of Management Studies, 28(2), 143-16o.

Larsen, P., Tonge, R., \& Ito, M. (200o). Managing the Strategic Planning Process: a comparative analysis between high-growth medium-sized enterprises and the general business population. Journal of Applied Management Studies, 9(2), 275-282.

Laycock, D. K. (1990). Are you ready for strategic planning. Non-profit World, 8(5), 25-27.

Leontiades, M., \& Tezel, A. (1980). Planning perceptions and planning results. Strategic Management Journal, 1(1), $65-75$.

Lynch, Richard (200o) corporate strategy, 2th Ed, prentice-Hall.

Mara, C. M. (200o). A strategic planning process for a small nonprofit organization: A hospice example. Nonprofit management and leadership, 11(2), 211-223.

Martin, R. (2005). Thinking about regional competitiveness-critical issues.

McKiernan, P., \& Morris, C. (1994). Strategic planning and financial performance in UK SMEs: does formality matter?. British Journal of Management, 5, S31-S41.

Moutinho, L., \& Hutcheson, G. D. (2011). The SAGE dictionary of quantitative management research. Sage Publications.

National Institutional Accreditation Standards for Higher Education Institutions in Iraq (2018) National Institutional Accreditation Standards of the Iraqi Ministry of Higher Education and Scientific Research.

Nayga Jr, R. M., \& Baga, L. M. (1995). Economic reforms and firm level strategic planning. Agribusiness, 11(6), 565572.

Newall, J. E. (1992). The challenge of competitiveness. Business quarterly, 56(4), 94-100.

Notarantonio, E. M., Quigley Jr, C. J., \& Cardente, R. E. S. (200o). The importance of marketing in the strategic planning process: a parish example. Journal of Ministry Marketing \& Management, 6(2), 1-18.

Odom, R. Y., \& Boxx, W. R. (1988). Environment, planning processes, and organizational performance of churches. Strategic Management Journal, 9(2), 197-205. 
Oughton, C. (1997). Competitiveness policy in the 1990s. The Economic Journal, 107(444), 1486-1503.

Pearce, J. A., Robbins, D. K., \& Robinson Jr, R. B. (1987). The impact of grand strategy and planning formality on financial performance. Strategic management journal, 8(2), 125-134.

Pickton, D. W., \& Wright, S. (1998). What's swot in strategic analysis?. Strategic change, 7(2), 101-109.

Poister, T. H., \& Streib, G. (2005). Elements of strategic planning and management in municipal government: Status after two decades. Public administration review, 65(1), 45-56.

Poister, T. H. (2005). Strategic planning and management in state departments of transportation. International Journal of Public Administration, 28(13-14), 1035-1056.

Porter, Michael (1990) what is strategy, Harvard business review.

Powell, T. C. (1992). Research notes and communications strategic planning as competitive advantage. Strategic management journal, 13(7), 551-558.

Ramanujam, V., Venkatraman, N., \& Camillus, J. C. (1986). Multi-objective assessment of effectiveness of strategic planning: a discriminant analysis approach. Academy of management Journal, 29(2), 347-372.

Ramanujam, V., \& Venkatraman, N. (1987). Planning system characteristics and planning effectiveness. Strategic Management Journal, 8(5), 453-468.

Raman, S. R. (2009). Middle managers' involvement in strategic planning: an examination of roles and influencing factors. Journal of General Management, 34(3), 57-74.

Rhyne, L. C. (1985). The relationship of information usage characteristics to planning system sophistication: An empirical examination. Strategic Management Journal, 6(4), 319-337.

Scott, B. R., Lodge, G. C., \& Bower, J. L. (1985). US competitiveness in the world economy. Harvard Business School Press.

Sinha, D. K. (1990). The contribution of formal planning to decisions. Strategic Management Journal, 11(6), 479492.

Sirmon, D. G., \& Hitt, M. A. (2003). Managing resources: Linking unique resources, management, and wealth creation in family firms. Entrepreneurship theory and practice, 27(4), 339-358.

St-Hilaire, W. G. A. (2011). Empirical evaluation test of the strategic planning process on the overall performance of the company. Global Journal of Management and Business Research, 11(1).

Thierstein, A., \& Abegg, C. (2003). The impact of the liberalisation of public services on the competitiveness of firms in the Alpine regions of Switzerland.

Thwaites, D., \& Glaister, K. (1992). Strategic responses to environmental turbulence. International Journal of Bank Marketing.

Veliyath, R., \& Shortell, S. M. (1993). Strategic orientation, strategic planning system characteristics and performance. Journal of Management studies, 30(3), 359-381.

Whitman, M. E., \& Woszczynski, A. B. (Eds.). (2004). The handbook of information systems research. Igi Global.

Wilkerson, T., (2007) all about strategic planning, a resource of the heart health resource center.

Williams, S. L., (2002). Strategic planning and organizational values: Links to alignment. Human Resource Development International, 5(2), 217-233.

Yasai-Ardekani, M., \& Haug, R. S., (1997). Contextual determinants of strategic planning processes. Journal of Management Studies, 34(5), 729-767.

Yasai-Ardekani, M., \& Nystrom, P. C., (1996). Designs for environmental scanning systems: Tests of a contingency theory. Management Science, 42(2), 187-204.

Young, R. D., (2003). Perspectives on Strategic Planning in the Public Sector. Columbia: Institute for Public Service and Policy Research, Universidad de South Carolina.

Zahra, S. A., Hayton, J. C., \& Salvato, C., (2004). Entrepreneurship in family vs. non-family firms: A resourcebased analysis of the effect of organizational culture. Entrepreneurship theory and Practice, 28(4), 363-381.

Zomorrodian, A., (2011). New approach to strategic planning: The impact of leadership and culture on plan implantation via the three cs: cooperation, collaboration and coordination. Collaboration and Coordination (March 4, 2011). 